\title{
Human herpes virus-8 associated primary effusion lymphoma of the pleural cavity in HIV-negative elderly men
}

\author{
V. Ascoli*, C. Carnovale Scalzo*, C. Danese**, K. Vacca**, A. Pistilli ${ }^{+}$, F. Lo Coco ${ }^{+}$
}

\begin{abstract}
Human herpes virus-8 associated primary effusion lymphoma of the pleural cavity in HIVnegative elderly men. V. Ascoli, C. Carnovale Scalzo, C. Danese, K. Vacca, A. Pistilli, F. Lo Coco. (C) ERS Journals Ltd 1999.

ABSTRACT: Human herpes virus-8 (HHV-8)-associated primary effusion lymphoma (PEL) is an unusual lymphoma confined to the body cavities, which primarily affects human immunodeficiency virus (HIV)-positive men at high risk for Kaposi's sarcoma (KS). We describe two HIV-negative elderly Italian men, who developed pleural HHV8-positive PEL in association with other diseases (systemic hypertension, colonic carcinoma, chronic obstructive airways disease, dilated cardiomyopathy), but without KS. Thoracic computed tomography revealed unilateral pleural effusion and pleural thickening. Thoracentesis disclosed large lymphoma cells, with no T- or B-cell associated antigens, clonal rearrangement of the immunoglobulin heavy chain gene and the presence of $\mathrm{HHV}-8$ but not Epstein-Barr virus deoxyribonucleic acid sequences.

Our cases differ from most pleural effusion lymphomas, in that they are nonacquired immunodeficiency syndrome-related. This highlights the possible human herpes virus-8-associated primary effusion lymphoma risk among elderly human immunodeficiency virus-negative patients, particularly Italians, in whom human herpes virus-8 seroprevalence rates and incidence of classic Kaposi's sarcoma are high. Eur Respir J 1999; 14: 1231-1234.
\end{abstract}

*Anatomia Patologica, Dipartimento di Medicina Sperimentale e Patologia, **II Clinica Medica, and Dipartimento di Biotecnologie ed Ematologia, Ospedale Policlinico Umberto $\mathrm{I}^{\circ}$, Università "La Sapienza" Roma, Italy.

Correspondence: V. Ascoli, Anatomia Patologica, Dipartimento di Medicina Sperimentale e Patologia, Viale Regina Elena 324, 00161 Rome, Italy. Fax: 39 064940896

Keywords: Ageing

human herpes virus-8

Italy

Kaposi's sarcoma

pleural cavity

primary effusion lymphoma

Received: July 291998

Accepted after revision April 231999
Primary effusion lymphoma (PEL) is a rare non-Hodgkin's lymphoma of B-cell origin, in which tumour cells contain deoxyribonucleic acid (DNA) sequences of a new herpes virus known as Kaposi's sarcoma (KS)-associated herpes virus or human herpes virus-8 (HHV-8) [1]. The disease has been predominantly described in homosexual and bisexual men with advanced human immunodeficiency virus (HIV) infection, but rarely in HIV-negative individuals, in Europe and in the USA [1-4]. Peculiar features of PEL include: 1) a propensity to proliferate in the fluids of body cavities with infiltration of the serosal linings, usually in the absence of tumour mass(es) and/or lymph node involvement; 2) large-cell morphology with null immunophenotype; and 3) a B-cell genotype. Recent studies indicate that the normal counterpart of PEL tumour cells is the mature B-cell, of preplasma cell nature [5].

In addition to occurring in PEL, HHV-8 DNA sequences are found in multicentric Castleman's disease and KS [6], which, before the acquired immune deficiency syndrome (AIDS) epidemic, typically affected the elderly. Although viral sequences can be recovered from the peripheral blood mononuclear cells of healthy blood donors [7], serological studies have shown that HHV-8 infection is not ubiquitous in most populations [8]. In Italy, however, HHV-8 seroprevalence and incidence of classic KS are higher, as compared to those recorded in the USA and other Northern European countries [8-10].

We describe two elderly Italian HIV-negative patients with HHV-8-positive pleural PEL, and review the few recent reports of non-AIDS-related HHV-8-positive PEL. Our study suggests a possible relationship between immunosenescence and the development of non-AIDS PEL. Its frequency is probably underestimated, at least in Italy, a geographical area at high risk for KS, and thus conceivably also for PEL.
Methods

\section{Patients}

Two elderly HIV-negative individuals developing nonBurkitt's lymphomatous effusions in the absence of extranodal or node-based lymphoma were identified among 3,418 with serous effusions examined at the Dept of Pathology of the Policlinico Hospital (Rome, Italy) between January 1991 and December 1997.

\section{Samples}

Aliquots of pleural fluids were received following diagnostic thoracentesis, and cell pellets were examined using Papanicolaou and May-Grünwald Giemsa-stained cytospins. Cells recovered from patient 1 were cryopreserved in $10 \%$ dimethyl sulphoxide $/ 20 \%$ foetal calf serum in minimal essential medium.

\section{Immunophenotypic characterization}

The immunophenotypic profile of the cell populations was determined by means of immunoperoxidase-staining of acetone-fixed cytospins using a labelled streptavidin/biotin method and monoclonal antibodies directed against CD5, CD15, CD19, CD20, CD22, CD45, CD45R0, CD68, CD30 (Ki-1), epithelial membrane antigen (EMA), vimentin and cytokeratin (clone CKMNF116). All reagents were supplied by Dako (Glostrup, Denmark), except CD22 and anti-CD15 (BectonDickinson, San Jose, CA, USA). Flow cytometry, a more desirable means of determining immunophenotype in suspected lymphomas, was not performed because of the scarcity of the specimens. 


\section{Molecular studies}

Genomic DNA was extracted from cryopreserved cell suspension in patient 1 , and from alcohol-fixed cells of previously Papanicolaou-stained slides in patient 2 , since only a limited amount of cells was obtained from the pleural fluid in this patient. Polymerase chain reaction (PCR) to detect HHV-8 DNA sequences was performed using the primers and conditions described elsewhere [11]. PCR experiments for HHV8 detection included the coamplification of DNA extracted from a HHV-8-positive KS biopsy as positive control. In addition, in order to assess the integrity of the DNA, a 215-base pair (bp) fragment of the noncoding $5^{\prime}$ region of the $\mathrm{Bcl}-6$ gene was coamplified using the primers $5^{\prime}$-AGGAAGGAGGGGAATTAG-3' and 5'-AAGCAGTTTGCAAGCGAG-3'. PCR analysis of Epstein-Barr virus (EBV) DNA sequences was performed using primers representative of the EpsteinBarr virus-associated nuclear antigen-2 region [12]. In case 1 , the genomic configurations of the immunoglobulin heavy chain (IgH), $c-m y c, B c l-2$ and $B c l-6$ genes were investigated by means of Southern blot analysis using the probes and experimental conditions reported elsewhere $[13,14]$. In case 2 , the IgH gene configuration was analysed via PCR amplification using the following primers: FR3A (5'-ACACGGCCGTGTATTACTGT-3'), LJH (5'-TGAGGAGACGGTGACC-3'), and VLJH (5'-GTGACCAGGGTACCTTGGCCCCAG-3').

\section{Results}

\section{Report of two cases}

Case 1. An 89-yr-old man, with a remote history of malaria (1936), systemic hypertension, surgery for lumbar intervertebral disk herniation (1984) and large bowel adenocarcinoma (1994), was admitted to the hospital in June 1995 because of dyspnoea. Laboratory data disclosed: red blood cell count $3.47 \times 10^{6}$ cells $\cdot \mu \mathrm{L}^{-1}$, haemoglobin concentration $10 \mathrm{~g} \cdot 100$ $\mathrm{mL}^{-1}$, white blood cell count $7.9 \times 10^{3}$ cells $\mu \mathrm{L}^{-1}(\mathrm{CD} 4+$ count was not performed), erythrocyte sedimen-tation rate (ESR) $70 \mathrm{~mm} \cdot \mathrm{h}^{-1}$, platelet count $191 \times 10^{3}$ cells $\cdot \mu \mathrm{L}^{-1}$, iron concentration $18 \mu \mathrm{g} \cdot \mathrm{dL}^{-1}, \gamma$-globulin concentration $1.8 \mathrm{~g} \cdot \mathrm{dL}^{-1}(26 \%$, normal range $9.0-18.0 \%$ ), and serum lactate dehydrogenase (LDH) activity $239 \mathrm{IU} \cdot \mathrm{L}^{-1}$ (normal range $100-193 \mathrm{IU} \cdot \mathrm{L}^{-1}$ ). A total body computed tomography (CT) scan revealed loss of volume of the left hemithorax in comparison to the normal right side, and a mediastinal shift toward the affected side. There was also slight pleural thickening, and a moderate amount of basal pleural effusion. Cytological examination of the pleural fluid showed a malignant lymphoma (fig. 1). Pleural fluid LDH activity was $2,602 \mathrm{IU} \cdot \mathrm{L}^{-1}$ (pleural fluid $\mathrm{LDH} /$ serum $\mathrm{LDH}=10$, normal ratio $\leq 0.6$ ). The patient was lost to follow-up.

Case 2. A 75-yr-old man was hospitalized in August 1997 because of dyspnoea and chest pain. His medical history was notable for systemic hypertension, chronic obstructive airways disease, dilated cardiomyopathy, and surgery for lumbar intervertebral disk herniation, which required blood transfusion in 1980. Laboratory data included:red blood cell count $4.12 \times 10^{6}$ cells $\mu \mathrm{L}^{-1}$, haemoglobin concentration 12.3 g. $100 \mathrm{~mL}^{-1}$, white blood cell count $7.22 \times 10^{3}$ cells $\cdot \mu \mathrm{L}^{-1}$ with CD4+ count 1,052 cells $\mu \mathrm{L}^{-1}$ (normal range $493-1,772$ cells. $\left.\mu \mathrm{L}^{-1}\right)$, ESR $68 \mathrm{~mm} \cdot \mathrm{h}^{-1}$, platelet count $190 \times 10^{3}$ cells $\cdot \mu \mathrm{L}^{-1}$, $\gamma$-globulin concentrations $1.8 \mathrm{~g} \cdot \mathrm{dL}^{-1}(26 \%)$, iron concentration $20.4 \mu \mathrm{g} \cdot \mathrm{dL}^{-1}$ and serum LDH activity $161 \mathrm{IU} \cdot \mathrm{L}^{-1}$. The

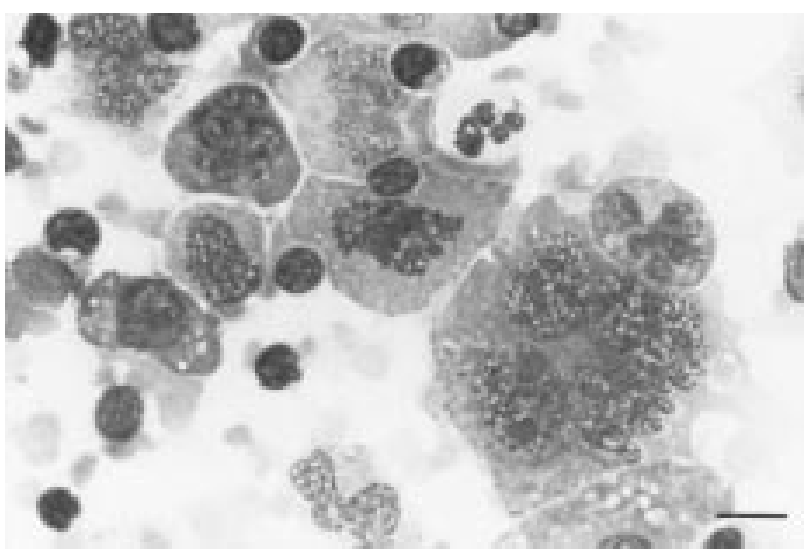

Fig. 1. - Pleural fluid sediment (case 1). A large Reed-Sternberg-like cell is seen adjacent to several plasmoblastic-like cells of different size, small lymphocytes and a neutrophil. At the centre is a tumour cell with atypical mitosis (May-Grünwald Giemsa). (Internal scale bar=10 $\mu \mathrm{m}$.)

CT scan showed contraction of the left hemithorax, thickening of the pleura and pleural effusion. Thoracentesis fluid showed malignant lymphoma (not shown). Pleural fluid LDH activity was $957 \mathrm{IU} \cdot \mathrm{L}^{-1}$ (pleural fluid LDH/serum LDH= 5.9). The patient is currently under clinical surveillance without any therapy, and is alive at 12 months follow-up.

Both patients were Italian-born (birthplaces: Puglia region, Southern Italy (case 1); and Lazio region, Central Italy (case 2). Patient 1 had lived in Puglia (Foggia province) during his whole life, whereas patient 2 had lived in Sardinia for many years, and then in Lazio (Rome). They were both seronegative for HIV and hepatitis B and C virus. Cultures of pleural fluids for aerobic, anaerobic, mycobacterial and fungal organisms yielded negative results. There was no evidence of lymphoadenopathy or tissue-based lymphoma based on CT scan findings. Neither of them had a history of previous or concomitant KS.

\section{Morphology and immunophenotype}

Cytological examination in both cases showed a population of medium-to-large-sized lymphoid cells intermixed with small lymphocytes, macrophages, neutrophils, eosinophils and rare mesothelial cells (fig. 1). Tumour cells had centrally or peripherally located irregular nuclei, prominent nucleoli and abundant deep basophilic cytoplasm. Bi- and multinucleate cells and very large cells with multilobate nuclei were common. Nuclear fragmentation, apoptosis and numerous mitotic figures were additional findings. Tumour cells were CD45-positive or negative, B-cell-associated antigen (CD20, CD19, CD22)-, T-cell-associated antigen (CD5, CD45R0)-, cytokeratin-, CD68-, and CD15-negative and EMA (focal)- and CD30 (focal)-positive. In case 1, a few lymphoma cells were vimentin-positive. Small lymphocytes were mostly T-cells $(\mathrm{CD} 5+/ \mathrm{CD} 45 \mathrm{R} 0+)$; other reactive cells were macrophages $(\mathrm{CD} 68+)$ and mesothelial cells (cytokeratin-positive).

\section{Molecular findings}

The HHV-8 DNA sequences were detected in DNA extracts from lymphoma cells in both cases (fig. 2). Clonal rearrangement of the $\operatorname{IgH}$ gene was detected in both cases. Owing to the small amount of available tumour cell DNA, 


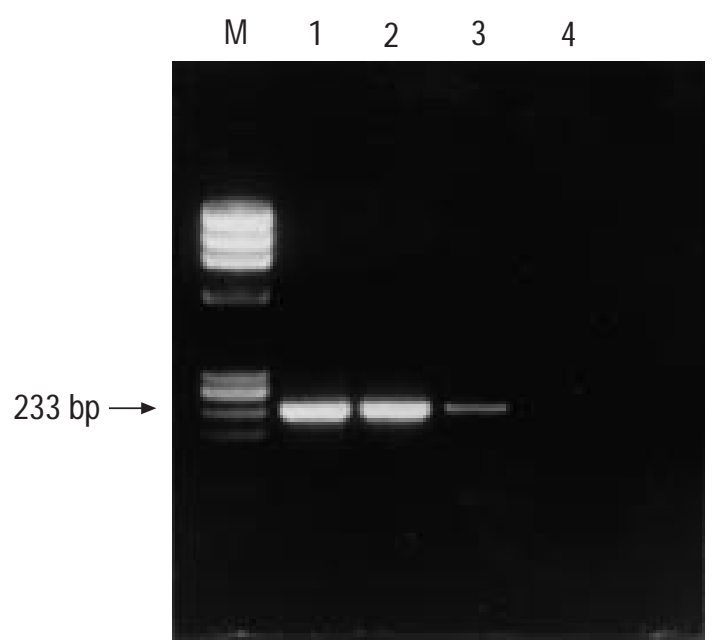

Fig. 2. - Polymerase chain reaction amplification of human herpes virus-8 (HHV-8) deoxyribonucleic acid (DNA) sequences. M: molecular size markers (ФX174 DNA/BsuRI (Haemophilus aegyptius III), which yield 11 discrete fragments of 1,353, 1,078, 872, 603, 310, 281, 271, 234, 194, 118 and 72 base pairs (bp)); 1: primary effusion lymphoma (PEL) (case 1); 2: PEL (case 2); 3: positive control (classic Kaposi's sarcoma, skin biopsy); 4: negative control (all reagents plus water instead

case 2 was only analysable by means of the PCR. No variation from the germ line configuration of control DNA was found by analysing $c-m y c, B c l-2$ and $B c l-6$ genes in case 1. The EBV genome was absent in both cases.

\section{Discussion}

According to the currently available literature, HHV- 8positive PELs occur rarely in HIV-negative individuals. To the best of the authors' knowledge, only six cases with a detailed description of clinicopathological features have been reported to date [1-4]. The main characteristics of our patients, and of the other described non-AIDS cases, are summarized in table 1 .

Non-AIDS PELs share several features with the more common AIDS-associated PELs, such as large-cell morphology, null immunophenotype, clonal IgH gene rearrangements, the presence of KS and lack of c-myc rearrangements. Distinguishing features consist of an older age on presentation, apparent host immunocompetence, infrequent EBV coinfection and an apparently less aggressive clinical course.

In our cases, the lymphomatous nature of the pleural effusion was an unexpected finding. Patients had no evidence of node-based or extranodal lymphoma, and fluid accumulation occurred in the course of other diseases. Laboratory abnormalities, including anaemia, moderate iron deficiency, a high ESR, hypergammaglobulinaemia and elevated serum/ pleural fluid LDH activities, were inconclusive. Relevant radiological findings included modest serosal thickening unaccompanied by pulmonary infiltrates and effusions. The diagnosis of PEL was initially suspected on the basis of the morphology (large cell) and immunophenotypic features of the pleural fluid population (CD45+, B-cell-associated antigennegative-/T-cell-associated antigen-negative), and the absence of a nodal or extranodal lymphoma other than in the pleural cavity. A final diagnosis of HHV-8-associated PEL was established following molecular evidence of B-cell clonality and HHV-8 infection in tumour cells.

The risk of developing PEL is possibly linked to decreased immunological surveillance, as suggested by its high frequency in AIDS individuals [1]. In the apparently immunocompetent host, the mechanisms underlying PEL development are less clear. However, the occurrence of PEL in elderly individuals (see table 1 and the present cases) suggests that a certain degree of immunodepression and/or immunodyeregulation may also be present in these cases. Ageing is notoriously associated with low T-cell immunoresponsiveness and a normal/increased humoral response, probably resulting from an imbalance in cytokine production [15]. The frequent concomitance of other diseases (second primary malignancies or cardiac failure/systemic hypertension) observed in our cases and in previously reported subjects with non-AIDS PEL [1], as well as in patients with classic KS [9], suggests an additional potential risk factor. Thus, underlying chronic disorders and age-related immunosenescence [15] represent the background against which non-AIDS PEL development may occur, possibly through HHV-8- mediated cytokine dysregulation in HHV-8 infected individuals [16].

It should be pointed out that our PELs showed epidemiological analogies with KS, another HHV-8-associated disease $[17,18]$. The birthplace and area of residence of our patients (South/central Italy and Sardinia) are considered as risk indicators for KS [17]. Moreover, the history of malaria in case 1 is in keeping with the fact that in places in which KS is endemic, malaria is common [18]. Both HHV-8 seroprevalence and the incidence of classic KS ( 1 per 100,000 males)

Table 1. - Human herpes virus-8-related primary effusion lymphomas in non-acquired immune deficiency syndrome patients

\begin{tabular}{|c|c|c|c|c|c|c|c|c|}
\hline $\begin{array}{l}\text { First author } \\
\text { [Ref.] }\end{array}$ & $\begin{array}{l}\text { Age } \\
\text { yrs }\end{array}$ & Sex & Origin & Body cavity & $\begin{array}{l}\text { Kaposi's } \\
\text { sarcoma }\end{array}$ & $\begin{array}{l}\text { Underlying } \\
\text { conditions }\end{array}$ & EBV & Outcome \\
\hline CARBone [2] & 69 & $\mathrm{~F}$ & Italy & Peritoneal & No & Cirrhosis & + & Died, 1 month \\
\hline \multirow{2}{*}{ NADOR [1] } & 85 & $\mathrm{M}$ & USA & Pleural & No & Congestive heart failure & + & Died, 6 months \\
\hline & 78 & $\mathrm{M}$ & USA & Pleural & No & NR & - & Died, 6 months \\
\hline \multirow[t]{2}{*}{ SAID [3] } & 85 & $\mathrm{~F}$ & Russia & Pleural & Yes & Leg amputation & - & NR \\
\hline & 46 & $\mathrm{~F}$ & NR & Artificial & No & NR & - & NR \\
\hline Strauchen [4] & 94 & M & NR & $\begin{array}{l}\text { Pericardial, pleural, } \\
\text { peritoneal }\end{array}$ & Yes & $\begin{array}{l}\text { Hypertension, large- } \\
\text { bowel carcinoma }\end{array}$ & - & Died, 4 yrs \\
\hline \multirow[t]{2}{*}{ Present cases } & 89 & M & $\begin{array}{l}\text { Italy } \\
\text { (Puglia) }\end{array}$ & Pleural & No & $\begin{array}{l}\text { Malaria, hypertension, } \\
\text { large-bowel carcinoma }\end{array}$ & - & Lost to follow-up \\
\hline & 75 & M & $\begin{array}{l}\text { Italy } \\
\text { (Lazio) }\end{array}$ & Pleural & No & $\begin{array}{l}\text { Hypertension, COAD, } \\
\text { dilated cardiomyopathy }\end{array}$ & - & Alive, 12 months \\
\hline
\end{tabular}

*: related to the capsule of a silicone implant. EBV: Epstein-Barr virus; F: female; M: male; NR, not reported; COAD, chronic obstructive airways disease. 
are higher in Italy than in other Western countries [8, 9], particularly in Southern Italy [10]. Thus, it is conceivable that a sizeable proportion of healthy Italian adults are latently infected with HHV-8, and that the frequency of non-AIDS PEL (probably currently underestimated) might approximate to that of classic KS. Individuals of Southern/Eastern European ancestry [18] might also be at high risk.

Since the diagnosis of primary effusion lymphoma is based on the detection of human herpes virus- 8 deoxyribonucleic acid (its genetic hallmark) besides the demonstration of clonal immunoglobulin heavy chain gene rearrangements, the application of diagnostic molecular techniques to body cavitybased lymphomatous effusions is recommended. The development of reliable serological assays for human herpes virus- 8 antibodies will probably contribute to the identification of those subjects with past exposure to the virus, who may be at risk for human herpes virus-8 related diseases, including primary effusion lymphoma.

\section{Addendum}

Subsequent to the submission of the manuscript, two additional cases of human herpes virus-8-associated lymphomatous effusion in elderly human immunodeficiency virusnegative males have been reported (Okada T, Katano H, Tsutsumi H, et al. Body-cavity-based lymphoma in an elderly AIDS-unrelated male. Int J Hematol 1998; 67: 417-422. San Miguel P, Manzanal A, Garci Gonzalez G, Bellas C. Association of body cavity-based lymphoma and human herpesvirus 8 in an HIV-seronegative male. Report of a case with immunocytochemical and molecular studies. Acta Cytol 1999; 43: 299-302).

\section{References}

1. Nador RG, Cesarman E, Chadburn A, et al. Primary effusion lymphoma: a distinct clinicopathologic entity associated with the Kaposi's sarcoma-associated herpesvirus. Blood 1996; 88: 645-656.

2. Carbone A, Gloghini A, Vaccher E, et al. Kaposi's sarcomaassociated herpesvirus DNA sequences in AIDS-related and AIDS-unrelated lymphomatous effusions. $\mathrm{Br} J$ Haematol 1996; 94: 533-543.

3. Said JW, Tasaka T, Takeuchi S, et al. Primary effusion lymphoma in women: report of two cases of Kaposi's sarcoma herpes virus-associated effusion-based lymphoma in human immunodeficiency virus-negative women. Blood 1996; 88: 3124-3128

4. Strauchen JA, Hauser AD, Burstein D, Jimenez R, Moore PS, Chang Y. Body-cavity-based malignant lymphoma containing Kaposi's sarcoma-associated herpesvirus in an HIV- negative man with previous Kaposi sarcoma. Ann Intern Med 1996; 125: 822-825.

5. Gaidano G, Gloghini A, Gattei V, et al. Association of Kaposi's sarcoma-associated herpesvirus-positive primary effusion lymphoma with expression of the CD138/syndecan-1 antigen. Blood 1997; 90: 4894-4900.

6. Cesarman E, Knowles DM. Kaposi's sarcoma-associated herpesvirus: a lymphotropic human herpesvirus associated with Kaposi's sarcoma, primary effusion lymphoma, and multicentric Castleman's disease. Semin Diagn Pathol 1997; 14: 54-66.

7. Blackbourn DJ, Ambroziak J, Lennette E, Adams M, Ramachandran B. Infectious human herpesvirus 8 in a healthy North American blood donor. Lancet 1997; 349: 609-611.

8. Gao S-J, Kingsley L, Li M, et al. KSHV antibodies among Americans, Italians and Ugandans with and without Kaposi's sarcoma. Nature Med 1996; 2: 925-928.

9. Geddes M, Franceschi S, Barchielli A, et al. Kaposi's sarcoma in Italy before and after the AIDS epidemic. $\mathrm{Br} J$ Cancer 1994; 69: 333-336.

10. Whitby D, Luppi M, Barozzi P, Boshoff P, Weiss RA, Torelli G. Human herpesvirus- 8 seroprevalence in blood donors and lymphoma patients from different regions of Italy. $J$ Natl Cancer Inst 1998; 90: 395-397.

11. Moore PS, Chang Y. Detection of herpesvirus-like DNA sequences in Kaposi's sarcoma in patients with and those without HIV infection. N Engl J Med 1995; 332: 1181-1185.

12. Lin JC, Lin SC, De BK, Chan WC, Evatt BL. Precision genotyping of Epstein-Barr virus by polymerase chain reaction using three gene loci (EBNA- 2, EBNA-3C, and EBER): predominance of type A virus associated with Hodgkin's disease. Blood 1993; 81: 3372-3381. [Erratum, Blood 1993; 82: 2268].

13. Lo Coco F, Gaidano G, Louie DC, et al. p53 mutations are associated with histologic transformation of follicular lymphoma. Blood 1993; 82: 2289-2295.

14. Pescarmona E, De Sanctis V, Pistilli A, et al. Pathogenetic and clinical implications of Bcl-6 and Bcl-2 gene configuration in nodal diffuse large B-cell lymphomas. J Pathol 1997; 183: 281-286.

15. Roubenoff R, Harris TB, Abad LW, Wilson PW, Dallal GE, Dinarello CA. Monocyte cytokine production in an elderly population: effect of age and inflammation. J Gerontol A Biol Sci Med Sci 1998; 53: M20-26.

16. Samaniego F, Markham PD, Gendelman R, et al. Vascular endothelial growth factor and basic fibroblast growth factor present in Kaposi's sarcoma (KS) are induced by inflammatory cytokines and synergize to promote vascular permeability and KS lesion development. Am J Pathol 1998; 152: $1433-1443$.

17. Geddes M, Franceschi S, Balzi D, Arniani S, Gafà L, Zanetti R. Birthplace and classic Kaposi's sarcoma in Italy. $J$ Natl Cancer Inst 1995; 87: 1015-1017.

18. Franceschi S, Geddes M. Epidemiology and classic Kaposi's sarcoma with special reference to mediterranean population. Tumori 1995; 81: 308-314. 